\title{
Social Disorganization and Lack of Recognition Increase Stress Among the Street Children of Dhaka
}

\author{
Shidratul Moontaha Suha ${ }^{1} \&$ Dorottya $\mathrm{Sik}^{2}$ \\ ${ }^{1}$ PhD Student, Doctoral School of Sociology, Faculty of Social Sciences, Eötvös Loránd University (ELTE), \\ Budapest, Hungary \\ ${ }^{2}$ Assistant Professor, Department of Social Work, Faculty of Social Sciences, Eötvös Loránd University (ELTE), \\ Budapest, Hungary \\ Correspondence: Shidratul Moontaha Suha, Doctoral School of Sociology, Faculty of Social Sciences, Eötvös \\ Loránd University (ELTE), Budapest, Hungary. Tel: 36-70-603-4175. E-mail: moontaha@ student.elte.hu
}

Received: April 27, 2021

doi:10.5539/ass.v17n7p39
Accepted: June 5, 2021

Online Published: June 30, 2021

URL: https://doi.org/10.5539/ass.v17n7p39

\begin{abstract}
In recent years, concern about the most vulnerable of Bangladeshis, street children, has increased significantly. Urban life presents these children with immense challenges to their general development and their place in society. Through hypothesizing a theoretical framework, this paper evaluates the lives and situations of street children living in the capital, Dhaka. Having reviewed the relevant literature, the hypothesis is grounded on a theoretical framework that contextualizes the lives of children living on the streets of Dhaka. The study finds that due to social disorganization and a lack of recognition, further stress is placed upon the city's street children.
\end{abstract}

Keywords: street children, urban society, social disorganization, recognition, stress

\section{Introduction}

Children on the streets of Bangladesh lack sufficient support, care, protection, rehabilitation, and reintegration. In fact, with the exception of the efforts of only a few NGOs, street children are, for the most part, not included in the targets of mainstream development programmes. Their living conditions make them tough, defiant, and aggressive; indeed, their need for survival leads them to become involved in illegal activities such as mugging, stealing, drug addiction, and participation in the sex trade. Motivated by the ability to make a daily wage and the desire to live a "decent" life without adult supervision, the children living on Dhaka's streets are, albeit unwillingly, part of the problem which only serves to maintain the crime rate. Scholars across the globe have for years dissected the issue of the mental development of street children and found it to be a direct consequence of the environments in which they live (Nielsen, 2016). Without adequate, stable protection from their street families, street friends, and peers with whom they grow up, they learn to live, earn, and struggle throughout their lives on the street. The situation of the street children in Dhaka illustrates the necessity of conducting a rigorous study of the lives of Bangladesh's street children, as for initiatives to be put into action, the actual situation needs to be both identified and understood. Therefore, this paper, through the design of a theoretical framework and establishment of a rationale based on a review of relevant literature, aims to define and characterize street children and examine how social disorganization and a lack of recognition create strain among this vulnerable group.

\section{Defining Childhood, Children, and Street Children}

Social processes are dynamic and continuous, and the social relations of young children depend on societies where their lives are both fundamental and essential. From birth, children are dependent on their parents, especially on their mothers, or significant caregivers. Gradually, they start developing attachments within their surroundings, with their fathers, siblings, grandparents, and other relatives, and later with friends, teachers, and broader society. Historically, it has been observed that in different societies children are born into and brought up in interdependent relationships which may change from time to time. From early childhood to adulthood, such networks become increasingly large, and equilibrium emerges out of this dependency (Gabriel, 2017). The family has a prominent, indeed dominant, role in shaping a child's socialization and in contemporary society, where children are active generators of their own social and cultural capital. 
According to the Convention on the Rights of the Child, Article 1, "For the present Convention, a child means every human being below the age of eighteen years unless, under the law applicable to the child, the majority is attained earlier" (1989). Bangladesh is among the 194 countries that signed and ratified the Convention on the Rights of the Child [CRC] 1989. In Bangladesh, the National Child Policy 2011 and Children Act 2013 define children as "[...] include[ing]all individuals/persons under the age 18 (eighteen)" (Ministry of Women and Children Affairs, 2011 \& The Children Act, 2013).

Regardless of the legal definition of children, and academic discussions on the definition of childhood and cultural differences, childhood infers the existence of a separate safe space. The United Nations General Assembly, in adopting the Convention on the Rights of the Child, defined childhood as "a separate space from adulthood [and recognized that] what is appropriate for an adult may not be suitable for a child" (1989). English sociologists have maintained that childhood must be observed as an organic part of society and culture rather than a stage preceding this, thus children should be considered active agents in society (Endrödy-Nagy, O., 2018). This study, however, for all its discussion of the legal and rational definition of children, along with the sociological perspectives of childhood, does not deal with, nor define the category of street children.

A well-established social setting is very important for a child (Muthee, 2020). Social order may be adjudicated by how well children are treated (Makofane, 2014). Street children may be interpreted in different ways. "Street" can have different meanings, be this physical, social, cultural, or symbolic. It is a multilevel category and a complex context. Meanwhile, the re is no generic meaning of the term "street children". Ambiguous, equivocal definitions are a cause for concern, resulting in an abundance of explanations. In a few instances, phrases used to denote children dwelling on the streets vary in line with geographical areas. A study from North America and Western Europe makes no differentiation between the terms "homeless" and "street children", whereas in Africa, Asia, Eastern Europe, and Latin America the term "street children" is used to specifically identify children that lead "street lifestyles" who are not necessarily homeless.

The number of children who are at risk of leading a street lifestyle is estimated to be around one hundred million globally, covering (a) street dwelling kids, who have migrated and stay on the streets without their families, (b) street operating kids, who spend the vast majority of their time operating on the streets to earn a living, yet have homes they can return to, and (c) children of families who live on the streets (Deb, Sunny, \& Majumdar, 2020). These kids, without exception, are sufferers of abuse of all forms, violence, exploitation, and inhuman treatment, while their antisocial behaviour and criminality maintains their susceptibility and helplessness to similar forms of victimization (Deb, Sunny, \& Majumdar, 2020). In line with the definition of "children" and the conceptualization of the term "childhood", the term "street children" can be defined as those who live and survive on the streets of the world's major cities in order to meet their daily needs.

These street children (as with children who do not lack rights) go through a socialization process, thus in this study one of the main objectives is to identify exactly what comprises their living conditions. In doing so, it seeks to understand the importance of "socialization". The term "socialization" is used to denote the lifelong process by which an individual exists and distributes their skills and behaviours to enable them to live in society (Grusec \& Hastings, 2014). It is blatantly obvious that the family plays the most important role in shaping children's attitudes and developing their social values in relation to future socialization. The family creates a socialization process that can be intentionally or unintentionally generated from a grounded environment.

\section{A Life of Social Disorganization, A Lack of Recognition, and Stress among Urban Street Children}

Various theories attempt to explain sociological dilemmas and various underlying issues in the context of the contemporary world. Thus in this theoretical section Shaw and McKay's social disorganization theory is included within the framework, as it facilitates both the characterization and categorization of the structure of street children's day-to-day lives, which invariably are beset with violence, residential mobility issues, poverty, and an opportunity perspective. Additionally, reference is made to Honneth's recognition theory, as this identifies strategies for helping reintegrate street children into society. Finally, Robert K. Merton's theories of deprivation and anomalies are examined to identify what the influential factors are, along with the significant actors, and to establish how individuals and groups are affected by their surroundings.

Street children live in such a way that engaging with crime is almost a disease-like phenomenon, which summarizes the idea of social disorganization theory as identified in Chicago by Shaw and McKay (Shaw \& McKay, 1942). Measures of three central theoretical elements in Shaw and McKay's social disorganization perspective (poverty, residential mobility, and racial heterogeneity), and variables related to the subculture of violence, social control, and opportunity perspectives are apparent. Therefore, the subject, "street children", is the result of that socialization process, and the ultimate sequelae of aspects of social structure. In Dhaka, as in 
other urban centres, the involvement of street children in criminal activities is commonplace, if not the norm. According to social structure theorists, the fundamental reasons for their engagement in criminal activities are poverty, a lack of education, and an absence of marketable skills, in addition to inherent socio-cultural values (see Figure 2).

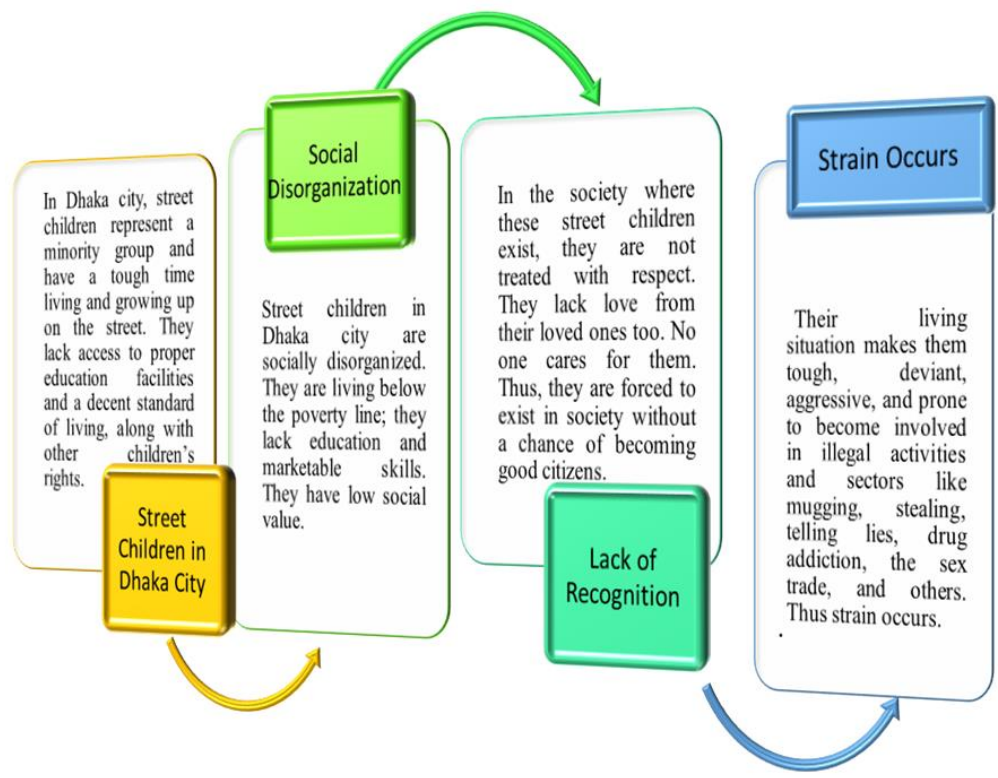

Figure 1. Disorganization in the Context of the Life of Street Children

Source: Author's construction using Pro Word Cloud, 2021.

Research conducted by Eamon M.K., with a sample group of children aged 10 to $12(\mathrm{~N}=963)$ from the National Longitudinal Survey of Youth (USA) found that neighbourhood problems and peer pressure, along with economic deprivation, are the leading contributory factors to social disorganization, which in turn can lead to child violence (2001). These factors are not dissimilar to those found in Bangladesh, where most street children living in Dhaka are victims of violence and are accustomed to a shortage of food and lack safe shelter, clean clothes, marketable skills, and medical facilities.

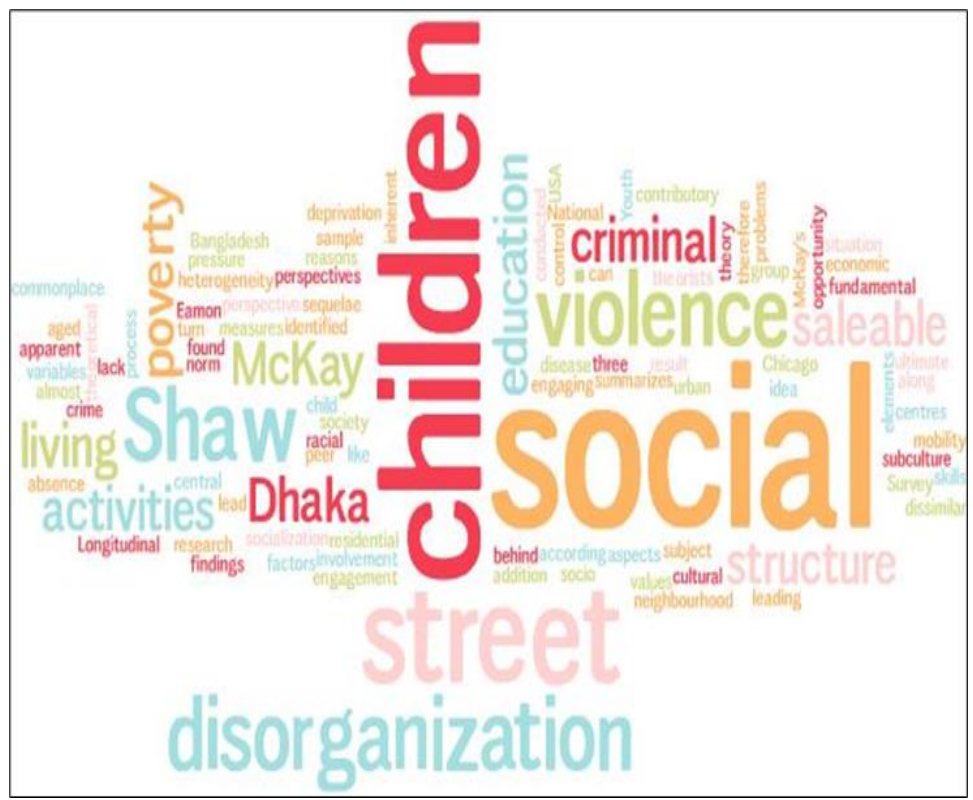

Figure 2. Social Disorganization among street children in Dhaka according to Shaw and McKay's Theory Source: Author's construction using Pro Word Cloud, 2021. 
Honneth's theory of recognition also has a direct correlation with the hardships endured by the street children of Bangladesh. In a notable work entitled 'The struggle for recognition: The moral grammar of social conflicts' (1995) and another called 'Disrespect: The normative foundations of critical theory' (2007), Axel Honneth states that the recognition process helps individuals to achieve personal self-government and self-realization intersubjectively (Thomas, 2012). This is linked to the theory of recognition - a wide-ranging and paradigm-shifting approach to re-connecting micro and macro-level sociological study of the development of street children living in urban areas, , and their everyday functioning through practicing protective agency (Atkinson \& Sheppard, 2017), which factors are implicitly linked to one of the objectives of this specific study.

According to Honneth, the first stage of recognition is deep-rooted in the human life cycle (Houston, 2015). In the same way that those children in society whose basic needs are met have emotional needs, so too do the most vulnerable: those living on the streets. When children's emotional needs are met, they grow to develop a self-confident identity, and become efficient enough to explore their skills through the factor of protective agency. The second stage of recognition is rights. In Bangladesh however, street children are perpetual victims of inequality and disempowerment, and effectively have no rights. The third and final form of recognition is a feeling of being unique within a social group, which is due to respect. Honneth specified the culturally defined goals which help an individual child to grow into a self-confident adult in the future. However, in Bangladeshi society, for the underprivileged street child, this is unimaginable (see Figure 3).

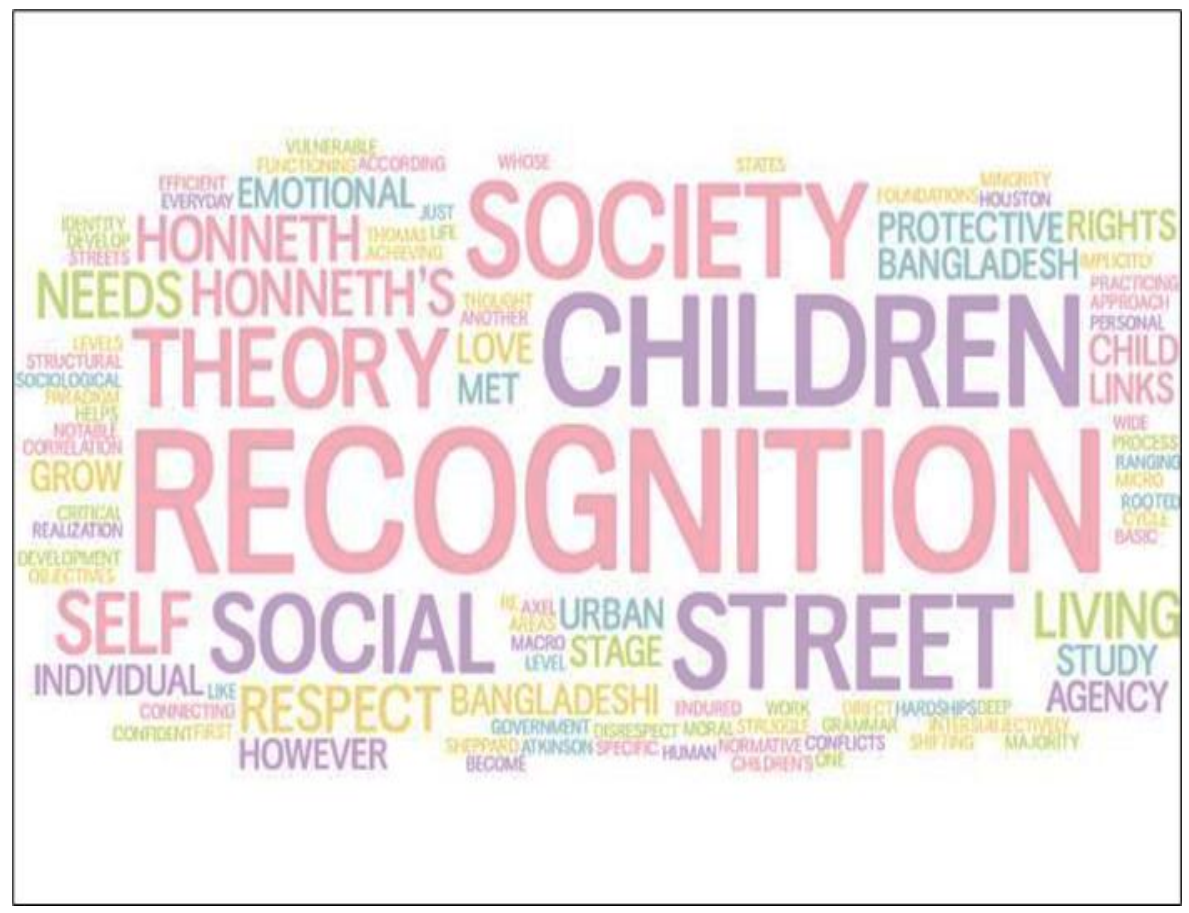

Figure 3. Lack of Recognition among Street Children in Dhaka according to Axel Honneth's Theory. Source: Author's construction using Pro Word Cloud, 2021

Thus, the theoretical notion of Honneth's Recognition theory is significant in Bangladeshi society, where, for some social actors, street children in urban centres are a means of maximising profits. Street children lack love, care, and respect in their social arena, and are never recognized as deserving citizens of the nation, nor of the society in which they are forced to survive. Furthermore, Honneth's theory suggests that for a better society, all children living in that society should be cared for through the provision of both the horizontal (love, respect, and esteem) and vertical aspects of recognition (Van Den Brink \& Owen, 2007, p. 26).

Observing that societal impressions vary from society to society, and from one social group to another, Robert K. Merton developed a theory of deviant behaviour in his 'Social Theory and Social Structure' (1949; rev. ed. 1968). The theory demarcates the interrelationship between social theory and experimental research. His structural-functional approach asserts the obvious function and dysfunction of society, which again, is an objective of this study. Of all the minority groups in Bangladesh, it is street children who experience the most difficulty acquiring an education and other basic children's rights (see Figure 4). 


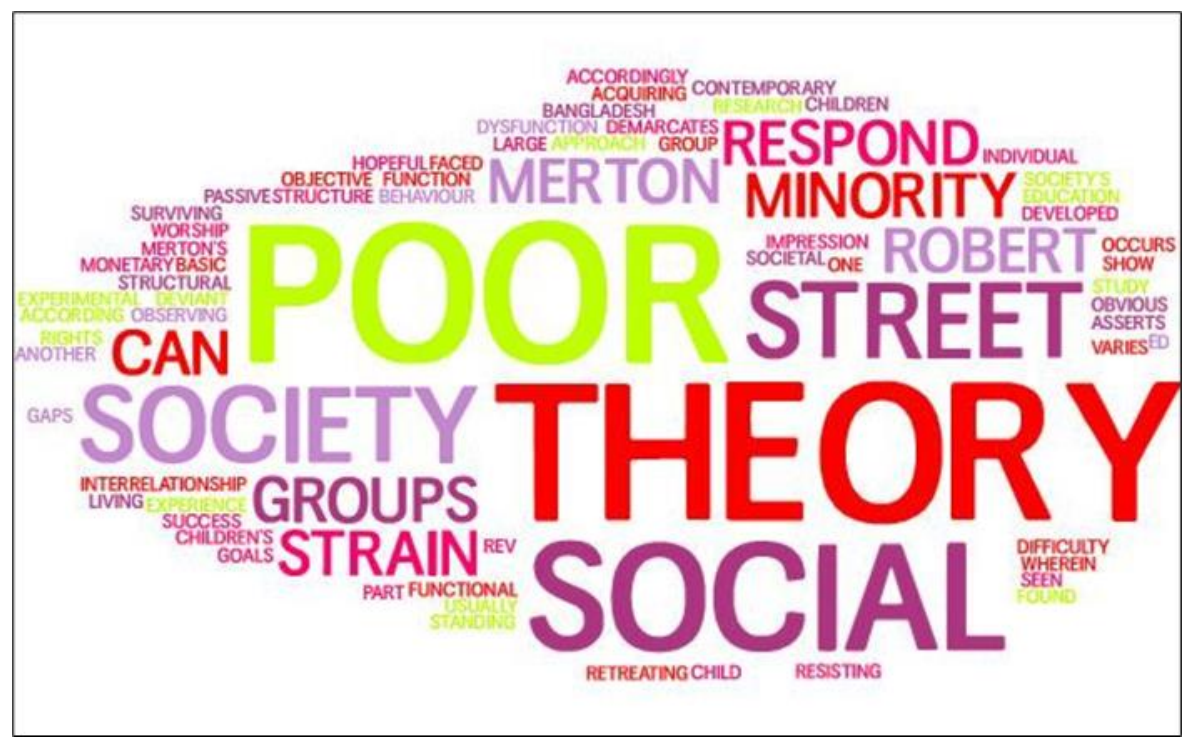

Figure 4. A Life of Stress among Street Children in Dhaka according to Robert K. Merton's Theory.

Source: Author's construction using Pro Word Cloud, 2021.

This illustrates Robert K. Merton's Strain theory, which describes street society's worship of "success". When these minority groups are faced with large gaps between their goals (usually monetary) and their contemporary standing, then strain occurs. According to Merton, individual children can be described as "hopeful poor", "surviving poor", "passive poor", "retreating poor" or "resisting poor", and those living on the streets may be classified accordingly (1938). Thus, one of the most influential theories, Axel Honneth's influential Recognition theory, along with Shaw and McKay's Social Disorganization Theory, and Robert K. Marton's strain theory (see Figure 1), are appropriate for describing the life and characteristics of street children of Dhaka.

Miscellaneous literature dissects the issue of the situation of street families across urban centres throughout Bangladesh. Children who are homeless in urban areas are arguably the most vulnerable of the remaining poor in society (in relation to others such as day labourers, rickshaw-pullers, domestic helpers, and hawkers). Though they share some characteristics with other poor people living in the same city, they have certain characteristics that make them stand out from those other helpless groups (Ibrahim, 2012). Ibrahim (2012) mentions six major factors: health care, assets, social network, infrastructural amenities, income, and shelter, the absence of which distinguishes the latter as street children and differentiates them from those children who belong to the other poor urban groups. UNICEF (2001) made a distinction between two remarkable groups of street children: "children of the street", who sometimes have links to their families, and "children on the street", meaning those who are accustomed to sleeping on the streets, and have no other option. A case study of slum settlements in Addis Ababa, Ethiopia, led to the claim that slums are one of street children's means of support, the basis of income, social networks, and housing for their inhabitants (Burns, 2007 in Ibrahim, 2012).

An ethnographic study by Whyte (1943) on the social structure of Italian slums formed the basis of subsequent studies regarding the functioning and development of street families across the globe. The author made pointed observations about the fact that archetypal poor communities living in urban areas should not ideally be subject to social disorganization (White, 1943). Aptekar dissected the issue of street children as a growing phenomenon in the developing world and made observations concerning the fact that the reasons for the existence of street children are primarily poverty, factors relating to modernization, as well as general abuse within family units (2013). The author examines how these street children cope at various psychological levels. In dissecting the topic, the author provides deep insight into potential reasons for the general prevalence of street families in different societies. In this regard, the author makes a cross-cultural comparison across various cultures that includes an analysis of this phenomenon in Colombia and Brazil (Aptekar, 2013). This study from Colombia and Brazil found that the issue of street children stems from the existence of dysfunctional families, punctuated by physical abuse and general neglect. This study questions the interrelation between such negligence and earlier theoretical material. In doing so, it intimates that, through negligence, a lack of care, love, and respect, destructively affects the futures of street children. As is the situation in Bangladesh, this type of negligence has not yet garnered enough research interest. 
Studies by Alem and Laha (2016) provide deep insight into the general mechanics of the development of street children by positing that the prevalence of the phenomenon is primarily a direct consequence of coercion by their immediate families, poverty, and the desire to eke out a daily livelihood. Nalkur (2016) conducted a comparative study of the general priorities of both street and non-street children and observed that risk was the common denominator among the two groups. Other researchers such as Cummings provided an analysis of the various factors that have led to the rise in the number of street children in major global urban centres, observing that poverty and general delinquency are critical factors in such development (2013).

Atkinson, S., Sheppard divulges the agency of street children by reflecting on current literature. The pattern of crime in Bangladesh, and the responsibility of children involved in crime groups (e.g. "the mastans" in Bengali language) are described in relation to some ethical and moral debates which build upon current theories of agency, but Sheppard proposes the concept of "protective agency" to help explain how and why children engage in organized crime (Atkinson \& Sheppard, 2017). On top of this, Weisburd D. and John E. Eck's review research article, 'What Can Police Do to Reduce Crime, Disorder, and Fear?' proposes that citizens feel safer due to community policing when it is not combined with problem-oriented approaches, which suggests that this approach could also result in a reduction in organized crime and disorder (2004). His study shows that street children are somehow engaged in deviant behaviour which is possible to control. Additionally, it is one of the targeted objectives of this study to identify the type of support, guidance, or life skills that street children need to improve or control their psycho-social development.

In 2003, twelve thousand Bangladeshi children under the age of eighteen were imprisoned for criminal activities; among these were vagrants, and others that were simply lost in Bangladesh (Mahajan, 2014, p. 208). In the same article, namely 'Child Rights in Bangladesh', the author set out to denote who could be defined as a child, what their basic rights are, how to stop child oppression, and finally, how the implementation of children's rights can be of benefit to the country. According to Mahajan (2014), Bangladeshi children are deprived of basic rights (e.g. education, a balanced diet, health and nutrition, protection, recreation, clean safe water, sanitation, and hygiene), and the major factors behind the routine violation of these rights include poverty, ignorance, a lack of social consciousness, and discrimination. This research reveals that among all children, street children are one of the more vulnerable groups, as they must find their own bread, clothing, and accommodation. Mahajan also found that the Bangladeshi government could benefit only by ensuring education for all, including street children, through compensation and subsidies (Mozdalifa, 2012 in Mahajan, 2014, p. 235). Raemdonck Laura V. and Khan Mariam S. propose intervention strategies for overcoming the remaining challenges - such as children who occasionally flee from home due to different forms of abuse, and suggest that street children should not be made subject to intervention programmes for long periods, which might result in them becoming hostage to aid (2017).

Another cross-sectional descriptive study was carried out to evaluate the risk behaviours of the street children in Dhaka in relation to determining health-related risk behaviours associated with food, clothing and shelter (Tahmina, Nasrin, Mamunur, Bedanta, \& Anthony, 2018). The findings of the study show that these vulnerable children are surviving by recycling rubbish, begging, or doing odd jobs which help them to eke out a living on the streets, where children's rights are, at best, ignored. Reza et al. (2019) underlined that for such children living in the street is not their fault and is inescapable. The study also posits that, in Bangladesh, street children are discriminated against in terms of class, gender, and power, which is often construed as offensive in relation to the power imbalance (Reza Md. \& Bromfield, 2019). Thus, Marton's understanding of deviance can be interpreted through the stress imposed on these children. This is becoming more deceptive from studies which reveal that, among all other forms of resource distribution, shelter is one that affects human biology through power relations (Ellis Meredith, 2019).

In general, street children encounter frequent upsets regardless of age, gender, and geographical concentration (Ballet, Sirven, Bhukth, \& Rousseau, 2011; Kipke, Simon, Montgomery, Unger, \& Iversen, 1997; Whitbeck, Hoyt, \& Ackley, 1997). Embleton L. et al. reported the major reasons for child and youth homelessness are poverty, abuse, family conflict, delinquency, and psycho-social health (2016). The findings of this research recommended that street children from all over the world need love and protection, as well as support or care from their respective governments to reduce socio-economic inequalities, which necessitates understanding of Honneth's aspects of recognition.

A qualitative study by Md. Hasan Reza which involved a sample of 75 street children aged 10-17 in the capital of Dhaka explored how the estimated 1-3 million street children of Bangladesh regularly cope with all kinds of violence, which varies due to age, gender, and location (2017). In an Egyptian study, it was found that $40 \%$ of participants are abused physically, whereas in Bangladesh (in relation to the same number of respondents and the same methodologies) the rate is 56\% (Mahmud, Ahsan, \& Claeson, 2011; Nada \& Suliman, 2010). It is 
universally recognized that street children are a distinct social group who barely enjoy human rights within their country's social and cultural traditions (Reza, 2016). In the last two decades, several international donor agencies along with the Bangladeshi government have been investing in and working for social sectors and have achieved some success in this regard. A study by Hossain Sheikh A. and Alam Md. A. found that most street children thought that their lack of education was the only reason that they were poor, which is why they predicted that education could help them escape their poor economic conditions (2016).

Instead of raising their self-esteem, living, and earning from the streets in the margins of society usually encourages children to develop self-destructive behaviours (Lieten \& Strehl, 2015). Similarly, in the same book the authors state that children may accept restrictions on their freedom in exchange for love, respect, and care. In an article entitled 'Street Children in the Developing World: A Review of Their Condition' there is a detailed account of the family structure of street children which might give us a sense of the general structure of a street family (Apteker, $1994 \& 2013$ ).

The nature of development not only varies from individual to individual, but also from group to group, and even from society to society. Therefore, street children who have their own way of development (Aptekar \& Stoecklin, 2014). A Columbian writer wrote in 1988 of two developmental stages of street children: 'gamines' and 'chupagruesos'. Gamines were more independent than chupagrueos and maintained their freedom and admitted their poverty. Meanwhile, when entering puberty, they were forced to make an important life decision to continue to live outside of conventional territory, knowing that failing to do so might lead them to become 'chupagruesic' by accepting the servile life of workers. This is highly significant, considering that most street children do not have conventional and satisfactory support at the family level. Abuse, abandonment, or negligent parents and guardians are commonplace, which factors challenge group formation and mutual support and hinder survival in society (Kilbride, 2000).

\section{Street Children in Dhaka}

Dhaka is referred to as an "enigma" in an article entitled 'Dhaka: Stressed but Alive!' in which the author mainly discusses how the city is highly stressed but still 'alive' through a focus on development, governance, and security (Ahmed, 2016). Ahmed defines Dhaka as originally a hydrological city where everybody comes and settles to improve their fate. Impoverished children, along with their parents, are included in this demographic. Figures 2, 3 and 4 illustrate how families came to escape poverty but instead started living on the streets - one of the numerous crises which have plagued Dhaka over the years.

Hardgrove (2017) mentions that the relationship between stigma and the emotional state of misery is very important. This feeling of misery among street youth has been understood as a practice of social demotion, which is common among the children living on the streets of Dhaka. It can make them feel down in a world where they do not have agency. Consequently, feelings of desolation or of misery (of not being cared for, being loved, or getting respect) are treated by others as experiences of contemptibility, of being unfit to live in society. It should be mentioned that the United Nations (UN) Convention on the Rights of the Child (UNCRC), along with the Government of Bangladesh (GoB), have engaged with the Convention on the Elimination of Discrimination against Women (CEDAW), and the Millennium Declaration to improve the survival, development, protection, and the participation of children and women (United Nations Children's Fund, UNICEF 2009). These two institutes have also engaged in initiatives related to the Millennium Development Goals (MDGs), which have since been expanded to incorporate Sustainable development Goals (SDGs).

Today's children are tomorrow's youth. Janette Habashi in a chapter entitled 'Introduction to Palestinian Youth Journaling Project' in the book Political Socialization of Youth mentioned that youth imitate social, economic, and political action to adjust to the current state of any nation's limited political structure (Habashi, 2017). In her writing, she also details how children and youth existing in disputed regions do not get the same rights to partake in organizational issues or in a politically aware system - for example, a democratic system. Such negligence leads to feelings of their being unwanted in the society in which they live, which does not motivate them to do their best for their future, adding to stress and strain (see Figure 4). This is how such children not only become a burden to themselves, but also to the nation.

A study comprising nineteen in-depth interviews and two key informant interviews with members of the street children community was conducted between February and May 2013 (Abdullah, Basharat, Lodhi, Wazir, Khan, Sattar, \& Zahid, 2014). Results of the study found that street children are, without exception, forced into altered social roles. The causes are health-related problems, poverty, and large families. These factors force them to enter the workforce to make a living. The authors also gathered information on the augmented hazards of both substance abuse among street children, and their sexual exploitation. The former conclude that such children are 
socially excluded and lead lives that limit their social roles in the society they belong to.

Bangladesh is a poor, overpopulated, and ill-governed nation where the government, along with international organizations, are working together to improve the economic and demographic situation (Chowdhury et al., 2017). Street children are habitually treated negligently and with dereliction. The related study was undertaken to evaluate the specific social problems that street children encounter in urban areas (Chowdhury et al., 2017). This research investigated the lives of street children and found their lives to be full of risk. This descriptive cross-sectional study was undertaken in several key points in Dhaka between May and June 2007, when the researchers met street children aged eight to fourteen of both sexes. The findings of the study reflect the fact that the primary reason for being a street child is, quite simply, poverty (Chowdhury et al., 2017).

Street children typically live in a precarious way. People around them, even families, do not care for them satisfactorily. From an early age they experience deprivation and stress, which results in a lack of productivity and negatively impacts their health throughout their lives. This truth is made clear in the article "A Forgotten Population: Estimating the Number of Children Outside of Households in Cambodia', which illustrated some recent efforts of Cambodian children living on the street or in other public places (Rubenstein \& Stark, 2016).

Finally, for some street children who sometimes visit their family and friends whilst also living and working on the street, stigmatization leads to them giving up on "middle-class" dreams of eventually marrying, working, being homeowners, and having children. Rather, they pass their days earning what they can, however they can, never knowing what dangers they might face. They do not dream about the future but live from moment to moment. This reinforces the claim that the given theoretical framework (See Figure 1) may be accepted as describing the persistent social structure of children living on the streets of Bangladesh.

\section{Conclusion}

The recent attention being paid to the plight of street children in urban centres has led several organizations to contribute to some meeting of their needs, regarding children's rights. But the activities of street children living in urban communities, especially in Dhaka, and the present situation show little or no improvement in terms of raising the latter's capabilities to maximize their well-being. To be very precise, this study found that, as social actors, children experience complex sensitive attachments. Captured in diversified street situations and having both obligations and being recipients of forms of aid, street life can thus be perceived as having a 'structure'. Children living on the streets of Dhaka seldom have access to education and lack all children's rights, including proper accommodation and protection. Due to social disorganization, they do not develop any kind of technical or social skills which might help them to become assets to the nation. Tragically, they do not get care and respect, let alone love, from those in society, which results in strain. Appealing for rights requires erudition, and nobody is born with this ability. Thus, children deserve social respect that are predominant in their setting. The notion of self-respect in terms of rights can hardly be developed among street children who continuously experience repercussions concerning their rights.

\section{Acknowledgments}

The research was financed from the EFOP-3.6.3-VEKOP-16-2017-00007 "from Talent to Young Researcher" project that supports researchers' academic careers in higher education.

\section{References}

Abdullah, M. A., Basharat, Z., Lodhi, O., Wazir, M. H. K., Khan, H. T., Sattar, N. Y., \& Zahid, A. (2014). A qualitative exploration of Pakistan's street children, as a consequence of the poverty-disease cycle. Infectious diseases of poverty, 3(1), 11 .

Ahmed, I. (2016). Building Resilience in Cities under Stress (pp. 13-23, Rep.) (MANCINI F. \& Ó SÚILLEABHÁIN A., Eds.). International Peace Institute. Retrieved December 29, 2020, from http://www.jstor.org/stable/resrep09526.6

Alem, H., \& Laha, A. (2016). The livelihood of Street Children and the Role of Social Intervention: Insights from Literature Using Meta-Analysis. Hindawi Publishing Corporation Child Development Research, 1(1), $1-13$.

Aptekar, L., \& Stoecklin, D. (2014). Street Children and Homeless Youth: A Cross-Cultural Perspective. Springer Dordrecht Heidelberg New York London.

Aptekar, L. (1988). Street children of Cali. Durham: Duke University Press.

Aptekar, L. (2013). Street Children in the Developing World: A Review of Their Condition (Masters). San Jose University. 
Apteker, L. (1994). Street Children in the Developing World: A Review of Their Condition. 28(3), 195-224. https://doi.org/10.1177\%2F106939719402800301

Atkinson, S., \& Sheppard. (2017). Street children and 'protective agency': Exploring young people's involvement in organized crime in Dhaka, Bangladesh. Childhood, 1-14.

Ballet, J., Sirven, N., Bhukuth, A., \& Rousseau, S. (2011). Vulnerability to the violence of girls of the street in Mauritania. Children and Youth Services Review, 33, 656-662. https://doi.org/10.1016/j.childyouth.2010.11.004

Burns, M. (2007). Slum settlements provide advantageous living conditions for low-income urban families: A case study from Addis Ababa, Ethiopia. Unpublished Master dissertation, University of Birmingham.

Chowdhury, S., Chowdhury, A. S., Huq, K. E., Jahan, Y., Chowdhury, R., Ahmed, T., \& Rahman, M. M. (2017). Lifestyle and risk behaviour of street children in Bangladesh: A health perspective. Health, 9(4), 577.

Cummings, P. (2013). Factors Related to the Street Children Phenomenon in Major Towns in Sierra Leone: A Comparative Study of the City's Street Children and Children in Normal Family Homes" (Masters). St. Clements University.

Deb, S., Sunny, A. M., \& Majumdar, B. (2020). Street Children: The Paradox of Untapped Human Resources. In Disadvantaged Children in India (pp. 1-47). Springer, Singapore.

Eamon, M. K. (2001). Poverty, parenting, peer, and neighbourhood influences on young adolescent antisocial behaviour. Journal of Social Service Research, 28(1), 1-23.

Ellis Meredith, A. B. (2019). The Children of Spring Street, The Bioarchaeology of Childhood in a 19th Century Abolitionist Congregation. Springer.

Endrődy-Nagy, O. (2018). A brief history of childhood-as seen on visuals. Didácticas Específicas, p. 103.

Gabriel, N. (2017). The sociology of early childhood: Critical perspectives. Sage.

Grusec, J. E., \& Hastings, P. D. (2014). Handbook of Socialization, Second Edition: Theory and Research. Guilford Publications.

Habashi, J. (2017). Introduction to Palestinian Youth Journaling Project. In Political Socialization of Youth. Palgrave Macmillan, New York. https://doi.org/10.1057/978-1-137-47523-7_1

Hardgrove, A. (2017). Life after guns: Reciprocity and respect among young men in Liberia (pp. 68-69). Rutgers University Press. Retrieved from https://www.jstor.org/stable/j.ctt1p0vkjj.7

Honneth, A. (2007). Disrespect: The Normative Foundations of Critical Theory. Polity Press, Cambridge.

Honneth, A. (1995). The Struggle for Recognition, The Moral Grammar of Social Conflicts. Polity Press, Cambridge.

Hossain, S. A., \& Alam, M. A. (2016). Socio-economic status of the street children in Bangladesh. International Journal of Social Work, 3(1), 42-49.

Houston, S. (2015). When I Look, I am Seen, So I Exist to Change: Supplementing Honneth's Recognition Model for Social Work. Social Work and Society, 13(2).

Ibrahim, A. (2012). Characteristics of Street Children (p. 1). Retrieved from https://www.e-ir.info/2012/12/11/characteristics-of-street-children/

Kilbride, P. (2000). Street children in Kenya: voices of children in search of a childhood. Greenwood Publishing Group.

Kipke, M. D., Simon, T. R., Montgomery, S. B., Unger, J. B., \& Iversen, E. F. (1997). Homeless youth and their exposure to and involvement in violence while living on the streets. Journal of Adolescent Health, 20, 360-367. https://doi.org/10.1016/S1054-139X(97)00037-2

Lieten, G. K., \& Strehl, T. (2015). Street Life. In Child Street Life. Springer Briefs in Well-Being and Quality of Life Research, 15. Springer, Cham. https://doi.org/10.1007/978-3-319-11722-5_4

Mahmud, I., Ahsan, K. Z., \& Claeson, M. (2011). Glue sniffing and other risky practices among street children in urban Bangladesh.

Makofane, M. (2014). A conceptual analysis of the label "street children": Challenges for the helping professions. Social Work, 50(1). 
Merton, R. K. (1949). On Sociological Theories of the Middle Range. S. 39-53 in Merton, Robert K. (Hg.), Social Theory and Social Structure.

Merton, R. K. (1938). Social Structure and Anomie. American Sociological Review, 3(5), 672-682. http://doi:10.2307/2084686. JSTOR 2084686

Merton, R. K. (1968). Social Theory and Social Structure (1968 enlarged ed.). New York, NY, US: Free Press.

Mohajan, H. K. (2014). Child Rights in Bangladesh, 2(1), 207-238.

Mozdalifa, J. (2012). Social Connection of Street Girls in the Context of Dhaka City. Unnayan Onneshan-The Innovators, Bangladesh.

Muthee, S. M. (2020). Determinants of Sustainability of Government Funded Street Children Rehabilitation Programs in Nairobi County, Kenya (Doctoral dissertation, University of Nairobi).

Nada, K. H., \&Suliman, E. D. (2010). Violence, abuse, alcohol and drug use, and sexual behaviours in street children of Greater Cairo and Alexandria, Egypt. Aids, 24, S39-S44.

Nalkur, P. (2016). When life is "difficult": A comparison of street children's and non-street children's priorities. Vulnerable Children and Youth Studies an International Interdisciplinary Journal for Research, Policy and Care, 1(1), 1-15.

National Children Policy 2011. (2011). Ministry of Women and Children Affairs, p. 3.

Nielson, R. (2016). The Application of Empowerment Theory to Street Children of the Developing World: The Case of Casa Alianza (Covenant House) in Honduras. British Columbia Journal, 1(1), 1-1.

Raemdonck, L. V., \& Khan, M. S. (2017). A case study on a generalist service delivery model for street children in Durban, South Africa: Insights from the capability approach. John Wiley \& Sons Ltd.

Reza, M. H. (2017). Street children's use of social support against everyday abuse in Bangladesh. Child \& Youth Services. https://doi.org/10.1080/0145935X.2017.1326307

Reza, Md. H., \& Bromfield, N. F. (2019). Human Rights Violations Against Street Children Working in the Informal Economy in Bangladesh: Findings from a Qualitative Study. Journal of Human Rights and Social Work. Springer Nature Switzerland AG 2019.

Reza, M. H. (2016). Poverty, violence, and family disorganization: Three "Hydras" and their role in children's street movement in Bangladesh. Child Abuse and Neglect, 55, 62-72. https://doi.org/10.1016/j.chiabu.2016.04.001

Rubenstein, B. L., \& Stark, L. (2016). A forgotten population: estimating the number of children outside of households in Cambodia. Global social welfare, 3(2), 119-124.

Shaw, C. R., \& McKay, H. D. (1942). Juvenile delinquency and urban areas; A study of rates of delinquents in relation to differential characteristics of local communities in American cities. Chicago: University of Chicago Press.

Tahmina, A., Nasrin, H., Mamunur, R., Bedanta, R., \& Anthony, L. (2018). Risk Behaviors of Street Children in Dhaka City. Bangladesh: A Cross Sectional Study. Medwin Publishers.

The Children Act 2013 XXIV (Ban).

The United Nations. (1989). Convention on the Rights of the Child. Treaty Series, 1577(November): 3, 2.

Thomas, N. (2012). Love, rights, and solidarity: Studying children's participation using Honneth's theory of recognition. Childhood, 19(4), 453-466.

UNICEF. (2001). Orphans and other vulnerable children and adolescents in Zimbabwe. Zimbabwe: UNICEF.

UNICEF. (2009). Situation Assessment and Analysis of Children and Women in Bangladesh.

Van Den Brink, B., \& Owen, D. (2007). Recognition and Power, Axel Honneth and the Tradition of Critical Social Theory (p. 26). Cambridge University Press.

Weisburd, D., \& Eck, J. E. (2004). What Can Police Do to Reduce Crime, Disorder, and Fear? American Academy of Political and Social Science, Sage Publications.

Whitbeck, L. B., Hoyt, D. R., \& Ackley, K. A. (1997). Abusive family backgrounds and later victimization among runaway and homeless adolescents. Journal of Research on Adolescence, 7, 375-392.

Whyte, W. (1943). Street Corner Society: The Social Structure of an Italian Slum (pp. 1-364). Chicago: 
University of Chicago Press.

\section{Copyrights}

Copyright for this article is retained by the author(s), with first publication rights granted to the journal.

This is an open-access article distributed under the terms and conditions of the Creative Commons Attribution license (http://creativecommons.org/licenses/by/4.0/). 